\title{
CHARACTERISTICS OF THE EXTRACELLULAR M PROTEINS OF GROUP-A STREPTOCOCCI
}

\author{
Alison M. Pinney and Jean P. Widdowson \\ Cross-Infection Reference Laboratory, Central Public Health Laboratory, \\ Colindale Avenue, London NW9 $5 \mathrm{HT}$
}

THE physicochemical properties attributed to streptococcal M proteins appear to depend upon the method of extraction from the cell wall. When extracted by $0.2 \mathrm{M} \mathrm{HCl}$ at $100^{\circ} \mathrm{C}$ (Lancefield, 1928), they exhibit considerable heterogeneity in size (Fox and Wittner, 1965 and 1969; Beachey, Alberti and Stollerman, 1969; Vosti, Johnson and Dillon, 1971; Strauss and Lange, 1972), due possibly to cleavage of the native protein by hot acid, to the aggregation of smaller protein subunits during or after extraction, or to a combination of these factors.

Treatment of M-type 3 and 12 organisms with alkali at $37^{\circ} \mathrm{C}$ yielded $\mathrm{M}$ proteins with a high average molecular weight of 120000 compared with 30000 in acid extracts of the same strains, suggesting that cleavage by hot acid is an important factor (Fox and Wittner, 1969). On the other hand, extraction with non-ionic detergent of M-types 6 and 12 yielded serologically active material composed of small homogeneous subunits with a molecular weight of about 30000 (Fischetti et al., 1973). The character of M protein also varies in different $M$ types: acid extracts of some opacity-factor (OF) positive serotypes have large molecular-weight fractions $(>80000)$ that contain all of the opacity factor and a major proportion of the $M$ protein, and smaller molecular-weight fractions that contain $\mathrm{M}$ protein but not OF. In contrast, acid extracts of members of OF-negative serotypes appear to contain little $M$ protein of high molecular weight, and serologically active fractions extending over a wide range (Widdowson et al., 1971a; Maxted and Widdowson, 1972).

The close physicochemical association and parallel type-specificity of $\mathbf{M}$ protein and $\mathrm{OF}$, and the fact that $\mathrm{OF}$ is found extracellularly (Widdowson, Maxted and Grant, 1970), prompted us to examine culture supernates for a potentially less modified form of $M$ protein than that obtained by the various extraction procedures. Previously (Olarte, 1948; Widdowson et al., 1971a), extracellular $\mathbf{M}$ protein had been demonstrated in some strains of group-A streptococci, but without quantitative estimation. We have now detected and measured the amount of $M$ protein in the culture supernates of OF-positive and OF-negative strains belonging to serotypes commonly associated with sore throat (" throat types ") and serotypes commonly associated with pyoderma ("skin types"; see Wannamaker, 1970), and also compared some of the physicochemical and immunological properties of extracellular and acidextractable $M$ proteins.

Received 9 Dec. 1976; accepted 4 Mar. 1977.

J. MED. MICROBIOL.—VOL. 10 (1977) 


\section{MATERIALS AND METHODS}

Streptococcal strains. The group-A streptococci used were classified by $T$ typing (Griffith, 1934) and M typing (Swift, Wilson and Lancefield, 1943). The representative collection of " throat" and "skin" $\mathbf{M}$ types used to detect extracellular $\mathbf{M}$ protein was obtained from lyophilised stocks in the Streptococcus Reference Laboratory, Colindale. Extracellular and cell-bound $\mathbf{M}$ proteins studied in greater detail were obtained from $M$-positive strains nos. R68/1115 (M-type 4), T5B (M-type 5), R55/1130, R68/3015, R66/3630, R53/1077 and R72/2992 (M-type 12), R71/461 (M-type 22), Quinn (M-type 30), R68/1544, B737/34 and C274/1 (M-type 49), R65/4127 (M-type 55), R67/3890 (M-type 57), R69/2709 (M-type 60) and PS346 (provisional M-type PS346). M-negative variants of strains SF59, R68/1115, R55/1130, R68/3116 and R68/1544 (see Widdowson, Maxted and Grant, 1970) were used in some experiments.

Sera. M-and T-typing antisera were prepared by the Streptococcus Reference Laboratory.

Growth of streptococci in broth. Todd-Hewitt Broth (Oxoid, Ltd, London), to which $1 \%(\mathrm{w} / \mathrm{v})$ Neopeptone (Difco) had been added, was used. Cultures were grown for $24 \mathrm{~h}$ at $37^{\circ} \mathrm{C}$ and centrifuged at $2000 \mathrm{~g}$ for $20 \mathrm{~min}$. to deposit the cells.

Lancefield extraction of cell-bound $M$ antigen. Deposited cells from $50 \mathrm{ml}$ of culture were washed twice in physiological saline, and extracted with $0.4 \mathrm{ml}$ of $0.2 \mathrm{M} \mathrm{HCl}$ at $100^{\circ} \mathrm{C}$ for $10 \mathrm{~min}$. The cooled extracts were neutralised with $0 \cdot 5 \mathrm{M} \mathrm{NaOH}$ after centrifugation and the supernates removed and stored at $-20^{\circ} \mathrm{C}$. Larger samples of extract for column chromatography were prepared from $500 \mathrm{ml}$ of culture; the cells were washed twice, suspended in physiological saline, adjusted to $p \mathrm{H} 2$ with hydrochloric acid and treated as described by Lancefield and Perlmann (1952).

Concentration with Carbowax. Broth supernates, saline cell-washings and chromatography fractions were concentrated 10-fold in dialysis bags suspended in Carbowax 6000 [Union Carbide (UK) Ltd, Hythe, Southampton] at $4^{\circ} \mathrm{C}$.

Precipitation with ammonium sulphate. Solid ammonium sulphate was added to measured volumes of broth supernate $(\mathrm{pH} 7 \cdot 8)$ to give a $66 \%$ saturated solution. After standing at $4^{\circ} \mathrm{C}$ for $24 \mathrm{~h}$, the precipitate was collected by centrifugation and dissolved in a fiftieth of the initial volume of distilled water. This preparation (the " P66" fraction) was dialysed against tap water at $4^{\circ} \mathrm{C}$ for $48 \mathrm{~h}$ to give a final concentration 20 times that of the starting material. Other preparations were made from both supernates in a similar manner at ammoniumsulphate percentage saturations of $20,40,50,60,70,80$ and 100 .

Column chromatography on Sephadex G100. Sephadex G100 (Pharmacia, Uppsala, Sweden) was soaked for 3 days at $4^{\circ} \mathrm{C}$ in veronal buffer, $p \mathrm{H} 8 \cdot 6, \mathrm{I}=0.033$ (diethylbarbituric acid $1.26 \mathrm{~g}$ and barbitone sodium $6.86 \mathrm{~g}$ in 1 litre of distilled water). After sedimentation and removal of fines by aspiration, the gel suspension was evenly packed into a column $30 \mathrm{~cm} \times 3 \mathrm{~cm}$. Columns were calibrated before use (Andrews, 1964) with a set of proteins of known molecular weight obtained from Boehringer Ltd (Mannheim). Void volumes were determined with Dextran Blue 2000 (Pharmacia Ltd). The sample ( 3 to $5 \mathrm{ml}$ ) was applied, washed-in twice with its own volume of veronal buffer, and eluted with veronal buffer, $p \mathrm{H} 8 \cdot 6$, at a flow rate of 40 to $50 \mathrm{ml}$ per h.

Isoelectric focusing of $M$ proteins. Volumes $(3 \mathrm{ml})$ of a $0 \cdot 2 \mathrm{M} \mathrm{HCl}$ extract and of a $\mathbf{P} 66$ fraction from strain R55/1130 (M-type 12 ) were dialysed overnight against glycine $1 \%(\mathrm{w} / \mathrm{v})$ to remove electrolytes. The dialysed samples were applied separately to a $110-\mathrm{ml}$ column (LKB Instruments Ltd, No. 8100-1) according to the procedure in the makers' manual (1-8100-E02), with the cathode at the top, and with $1 \%$ Ampholines in the $p \mathrm{H}$ range $3 \cdot 5-10$. The focusing experiments were continued at $10^{\circ} \mathrm{C}$ for at least $24 \mathrm{~h}$ at $600 \mathrm{v}$ and $1 \mathrm{~mA}$ after the $p \mathrm{H}$ gradient was established, so that the total running time was c. $48 \mathrm{~h}$. The power supply was switched off, the anode compartment was closed, and the contents of the column were pumped out from the bottom at a rate of $1 \mathrm{ml}$ per min. and collected in $2-\mathrm{ml}$ fractions. The $p \mathrm{H}$ of each fraction was measured at $10^{\circ} \mathrm{C}$ on a Dynocap $p \mathrm{H}$ meter (Pye Ltd, Cambridge) and the tubes were capped and stored at $-20^{\circ} \mathrm{C}$. $\mathrm{M}$ protein in the fractions was detected by double diffusion against absorbed anti-M serum in agar gels as described below. The Ampholine 
and sucrose in the fractions were found not to interfere with M-protein estimations, and so were not dialysed out before testing.

Estimation of protein. The protein content of fractions was determined by the method of Lowry et al. (1951) with bovine serum albumin as a standard.

\section{Detection of $M$ antigen}

By double diffusion in agar gel. $\mathrm{M}$ antigen in extracts, $\mathrm{P} 66$ fractions and column fractions was detected by double gel diffusion in $1 \%(\mathrm{w} / \mathrm{v})$ Ion Agar (Oxoid) in veronal buffer, $p \mathrm{H} \mathrm{8.6}$, $I=0.033$, against the specific absorbed anti-M serum and against a heterologous $M$-antiserum as a control. The titre of $\mathbf{M}$ antigen in a preparation was taken as the highest dilution showing a precipitate line in the gel.

By complement fixation. The method of Bradstreet and Taylor (1962) was employed. P66 preparations or acid extracts were used as antigen and absorbed rabbit-antiserum of homologous $\mathbf{M}$ type as antibody. Heterologous extracts and sera were included in the test to confirm that fixation of complement was the result of type-specific antigen and antibody combination. Three minimal haemolytic doses (3 MHD) of complement (Burroughs Wellcome freeze-dried guinea-pig serum) were used, and fixation took place at $4^{\circ} \mathrm{C}$ overnight. After adding sensitised sheep red-blood cells (prepared from Wellcome sheep blood in Alsever's solution), the tests were incubated at $37^{\circ} \mathrm{C}$ for $30 \mathrm{~min}$. with shaking after $15 \mathrm{~min}$. and $30 \mathrm{~min}$. The results were recorded after $2 \mathrm{~h}$ at $4^{\circ} \mathrm{C}$ as $4+=$ no haemolysis, $3+=$ slight haemolysis, $2+=50 \%$ haemolysis, $1+=$ almost complete haemolysis and $0=$ complete haemolysis.

Each rabbit anti-M serum was diluted 1 in 10 in buffer before use, incubated with 3 MHD of complement at $37^{\circ} \mathrm{C}$ for $30 \mathrm{~min}$. and then inactivated at $56^{\circ} \mathrm{C}$ for $30 \mathrm{~min}$. before further dilution. This procedure neutralised its anti-complementary activity.

By bactericidal neutralisation. This test measures the ability of a streptococcal product or fraction to inhibit the killing of the homologous streptococci by heparinised human blood known to contain the corresponding $\mathbf{M}$ antibody but to lack antibody to $\mathbf{M - a s s o c i a t e d}$ protein (see Widdowson, Maxted and Pinney, 1971b). A modification of the bactericidal test described by Maxted and Valkenburg (1969) was used.

Streptococcal extract or P66 fraction $(0.02 \mathrm{ml})$ was mixed in a small glass tube with an equal volume of a suitably diluted 3-4 h streptococcal culture containing 50-200 colony forming units per $0.02 \mathrm{ml} ; 0.3 \mathrm{ml}$ of human blood was added to each tube, the tubes were sealed and rotated end-over-end at $37^{\circ} \mathrm{C}$ for $3 \mathrm{~h}$. They were then opened and $0.02 \mathrm{ml}$ from each was inoculated into pour plates of Hartley digest agar (see Cruickshank, 1965) containing $10 \%(\mathrm{v} / \mathrm{v})$ of horse blood. After incubation at $37^{\circ} \mathrm{C}$ for $24 \mathrm{~h}$, the plate was examined and the results were recorded as $4+=$ confluent growth, $3+=>200$ colonies (but $<$ confluent growth), $2+=50$ to 200 colonies, $1+=$ up to 50 colonies, and $-=$ no growth.

\section{Detection of $O F$}

Fractions were tested for OF by incubating $0.2 \mathrm{ml}$ with $1 \mathrm{ml}$ of horse serum containing 1 in $5000(\mathrm{w} / \mathrm{v})$ merthiolate at $37^{\circ}$ for $18 \mathrm{~h}$. After incubation, $1.2 \mathrm{ml}$ of saline was added to each tube and the opacities were read at $475 \mathrm{~nm}$ in a Unicam SP600 spectrophotometer (Widdowson et al., 1971a).

\section{RESULTS}

\section{Detection of $M$ antigen in culture supernates and acid extracts by double gel diffusion}

$M$ antigen could not be detected in unconcentrated culture supernates but preliminary experiments with strains C274/1 (type 49) and R66/3630 (type 12) showed that $M$ protein was precipitated from solution at concentrations of ammonium sulphate of $>66 \%$ saturation. "Matching" extracts and concentrated supernate fractions (P66) were made, and the amount of $M$ protein 
was estimated by double diffusion in gel. Lines of identity were obtained between the acid-extracted and extracellular $M$ protein of the same type against the homologous absorbed anti-M serum. No lines were obtained against heterologous $\mathbf{M}$ antisera.

Influence of age of culture. To establish whether $\mathrm{M}$ protein was released into the supernate by autolysis of cells towards the end of the growth cycle, ammonium-sulphate precipitates (P66 fractions) of the supernate and acid extracts of the washed cells were prepared from a culture of a strain of provisional type PS346 at various stages of the growth cycle. M antigen was detected by double gel diffusion in the supernate at an early stage of the growth cycle and increased steadily in amount throughout the logarithmic phase. Group-A polysaccharide could not be detected in the extracellular material at any time, which suggested that extensive autolysis had not taken place (table I).

\section{TABLE I}

Influence of age of culture on extracellular M-protein and opacity-factor production by a strain of provisional type PS 346

\begin{tabular}{|c|c|c|c|}
\hline \multirow{2}{*}{ Age of culture (h) } & \multirow[b]{2}{*}{$\mathrm{E}_{600}$} & \multicolumn{2}{|c|}{${ }^{*}$ Titre of $M$ antigen in } \\
\hline & & $\begin{array}{l}\text { P66 fraction of } \\
\text { growth supernate }\end{array}$ & acid extract \\
\hline $\begin{array}{r}2 \\
4 \\
8 \\
16 \\
24\end{array}$ & $\begin{array}{l}0.16 \\
0.41 \\
0.96 \\
0.96 \\
0.96\end{array}$ & $\begin{array}{c}1 \\
1-2 \\
2-4 \\
8 \\
8\end{array}$ & $\begin{array}{r}1 \\
4 \\
8 \\
16 \\
16\end{array}$ \\
\hline
\end{tabular}

Absence of $M$ protein in cell washings. The possibility that some of the cellular $M$ protein is so loosely bound to the cell-wall that it simply washes off into the culture supernate was investigated by washing the cells of $18-\mathrm{h}$ cultures of strains C274/1 and R66/3630 three times with 50-ml volumes of physiological saline. No $M$ protein could be detected by precipitation in gel in any of the washings after 20 -fold concentration with Carbowax. The titre of acid-extractable cellular $\mathrm{M}$ protein was not reduced by this washing procedure and this suggested that the M protein in 18-h cultures is firmly bound to the cell-wall.

\section{Comparison of extracellular and acid-extracted $M$ antigen}

Sensitivity to heat, acid and proteolytic enzymes. The M-protein titres of acid extracts and P66 fractions from strains C274/1 (M-type 49) and 1130 (M-type 12), as measured by precipitation with the homologous absorbed $M$ antiserum in agar gel, were unaffected by heating at $95^{\circ} \mathrm{C}$ for $10 \mathrm{~min}$., at neutral $p \mathrm{H}$ or at $p \mathrm{H} 4 \cdot 0$. Extracellular and extracted $\mathrm{M}$ protein was destroyed by digestion with trypsin, pepsin and streptococcal proteinase at $37^{\circ} \mathrm{C}$ for $2 \mathrm{~h}$. 
Behaviour on isoelectric focusing. Isoelectric focusing of an acid extract of an M-type 12 strain (R55/1130) in the $p \mathrm{H}$ range 3.5 to 10 showed that $\mathrm{M}$

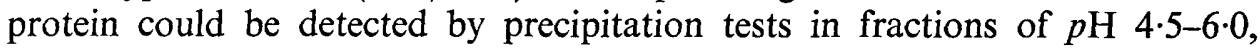
with a sharp peak at $p \mathrm{H} \mathrm{5.1} \mathrm{(figure).} \mathrm{The} \mathrm{M-protein} \mathrm{titre} \mathrm{of} \mathrm{the} \mathrm{P} 66$ fraction of the culture supernate of the same strain was considerably lower (4) than that of the corresponding extract (64). After isoelectric focusing of the P66 fraction in the $p \mathrm{H}$ range 3.5 to 10 , undiluted fractions from $p \mathrm{H} 4.5$ to 5.6 gave positive precipitation reactions with the absorbed type 12 anti-M serum. The reactions were strongest (but did not give a titre in excess of 2) in fractions of $p \mathrm{H} 4.8$ to 5.2. These results indicate that the isoelectric point of type-12 $\mathrm{M}$ protein is approximately 5.0 for both the acid-extracted and extracellular form.

\section{Comparison of methods for detecting $M$ protein in culture supernates}

To confirm the presence of $\mathrm{M}$ antigen in culture supernates we used two methods of detection additional to precipitation with the specific $\mathbf{M}$ antiserum.

Type-specific complement fixation. This was examined as a potentially more sensitive method of detection than double-gel diffusion. We selected five strains of M-type 12 that elaborated different amounts of extracellular $\mathbf{M}$ antigen, as measured by the double diffusion method against the same absorbed anti-M12 serum (table II). The type-specific complement-fixation titre of the serum (no. R1572/4, 5), determined by chequerboard titration against the homologous type-12 acid extract, was 160 . The absorbed serum did not fix complement with acid extracts of five heterologous $\mathrm{M}$ types including an

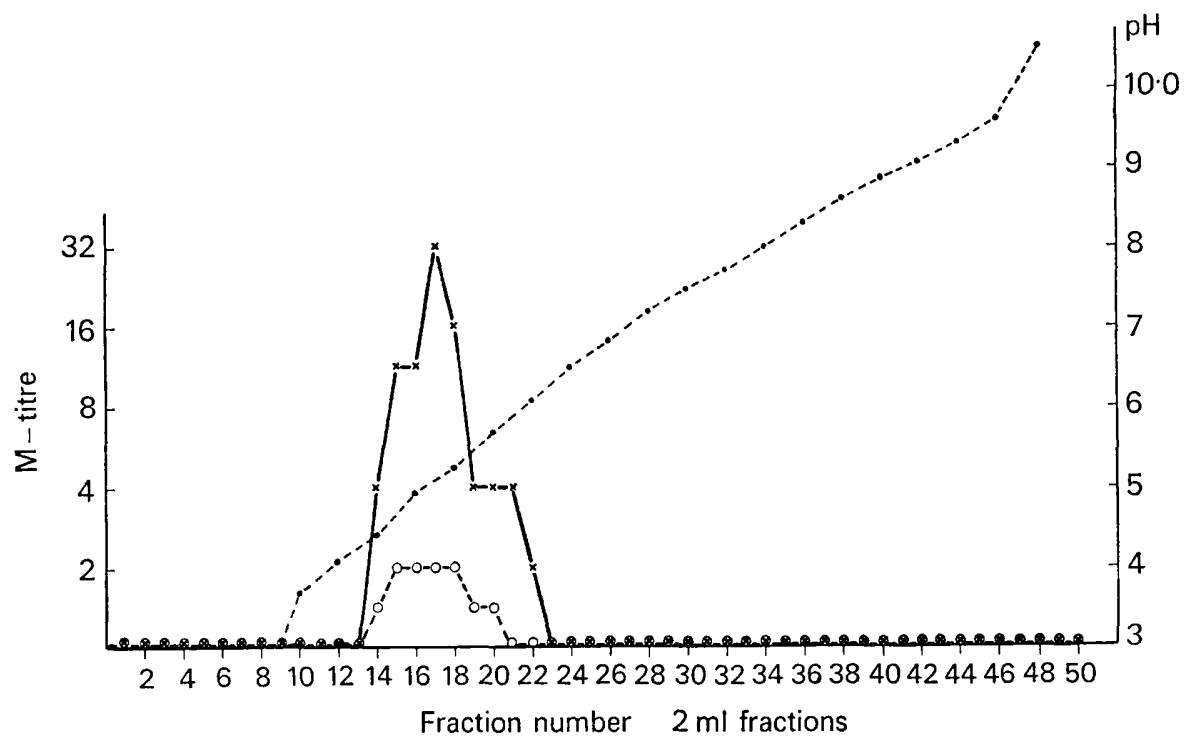

FIGURE-Isoelectric focusing (IEF) profiles of acid-extracted and extracellular M protein of an M-type 12 strain $(\mathrm{R} 55 / 1130) . \times \times=\mathrm{A} 0.2 \mathrm{M} \mathrm{HCl}$ extract $(\mathrm{M}$ titre $=64) ; \mathrm{O}-\mathrm{M}=\mathrm{O}$ concentrated growth supernate (P66 fraction, $\mathrm{M}$ titre $=4)$;

J. MED. MICROBIOL.-VOL. 10 (1977) 
TABLE II

Comparison of three methods of measuring the content of $M$ antigen in acid extracts and culture supernates (P66 fractions)

\begin{tabular}{|c|c|c|c|c|}
\hline $\begin{array}{c}\text { Strain } \\
\text { no.* }\end{array}$ & Preparation & $\begin{array}{c}\text { Precipitation } \\
\text { titre }\end{array}$ & $\begin{array}{l}\text { Complement- } \\
\text { fixation } \\
\text { titre }\end{array}$ & $\begin{array}{c}\text { Bactericidal } \\
\text { neutralisation } \\
\text { test result } \dagger\end{array}$ \\
\hline \multirow{7}{*}{$\begin{array}{c}\mathrm{R} 68 / 3015 \\
\mathrm{R} 68 / 3015 \\
\mathrm{R} 55 / 1130 \\
\text { matt } \\
\mathrm{R} 55 / 1130 \\
\text { matt } \\
\mathrm{R} 53 / 1077 \\
\mathrm{R} 72 / 2992 \\
\mathrm{R} 68 / 3630 \\
\mathrm{R} 55 / 1130 \\
\text { glossy } \\
\mathrm{R} 71 / 461\end{array}$} & $\begin{array}{l}\text { Supernate } \\
\text { Acid extract }\end{array}$ & $\begin{array}{r}0 \\
16\end{array}$ & $\begin{array}{r}80 \\
2560\end{array}$ & $\stackrel{+}{++}$ \\
\hline & Supernate & 4 & 320 & +++ \\
\hline & & & & \\
\hline & $\begin{array}{l}\text { Acid extract } \\
\text { Supernate }\end{array}$ & $\begin{array}{r}32 \\
4\end{array}$ & $\begin{array}{c}2560-5120 \\
320\end{array}$ & $\begin{array}{c}++++ \\
++\end{array}$ \\
\hline & Supernate & 4 & 320 & $+t$ \\
\hline & Supernate & 0 & 80 & \\
\hline & $\begin{array}{l}\text { Acid extract } \\
\text { Supernate }\end{array}$ & $\begin{array}{l}0 \\
0\end{array}$ & $\begin{array}{l}<40 \\
<40\end{array}$ & - \\
\hline
\end{tabular}

Extracts and P66 fractions from strains of heterologous $M$ types 18, 30, 55 and 60 gave negative results in all three tests.

* All strains contained T-antigen 12 and, except for R55/1130 glossy, were M-type 12.

$\dagger-=$ No growth (no neutralisation of "bactericidal " antibody); $+=$ up to 50 colonyforming units (c.f.u.); $++=55-200$ c.f.u.; $+++=>200$ c.f.u.; $++++=$ confluent growth (complete neutralisation of bactericidal antibody).

extract of a type T12, M22 strain, or with dilutions of a purified M protein from type 30 , indicating that the serum was free of antibody to T12 antigen, antibody to $\mathrm{M}$-associated protein, or other cross-reactive antigens. Preparations to be tested for type-12 M protein were titrated against a 1 in 40 dilution of this absorbed anti-M12 serum. The results in table II show that the complement fixing titres of acid extracts and P66 fractions were at least 80 times higher than the corresponding precipitation titres with the same serum. P66 fractions from two strains (nos. R66/3015 and R66/3630) that were negative in the geldiffusion test had complement fixing titres of 80 , indicating that the fractions contained small amounts of $\mathrm{M}$ protein undetectable by the less sensitive geldiffusion method.

Neutralisation of "bactericidal" antibody in human serum. This test was used to establish that the extracellular form of $\mathbf{M}$ antigen had the ability to neutralise homologous protective $M$ antibody in human serum. The P66 fractions of the culture supernates of the five M-type 12 strains (table II) and the acid extracts of strains $\mathrm{R} 55 / 1130(\mathrm{M}+)$ and $\mathrm{R} 66 / 3015$ were tested for ability to neutralise the bactericidal action of a human blood with naturally acquired type-12 M antibody. An inoculum containing 200 colony-forming units (c.f.u) of the test strain R53/1077 (M-type 12) failed to survive after incubation for $3 \mathrm{~h}$ in the heparinised blood alone, but in the presence of $0.02 \mathrm{ml}$ of four of the five P66 fractions and both acid extracts of the type-12 strains, numbers of survivors varied to produce from about 50 colonies to confluent growth in blood agar plates, indicating partial or complete neutralisation of antibody by the added antigen preparations. 
The number of surviving c.f.u. was roughly proportional to both the precipitin titre and the type-specific complement-fixation titres of the type-12 preparations. One P66 fraction, from strain R66/3630, did not neutralise the bactericidal action of the blood, and had no detectable $M$ antigen by the precipitin test and a titre of only 80 in the type-specific complement-fixation test. Another P66 fraction, from strain R66/3015, apparently contained little $\mathrm{M}$ antigen by the complement fixation test and had very poor neutralising activity. P66 fractions and acid extracts from heterologous M-types 18, 30, 55 and 60, and the P66 fraction from uninoculated broth did not affect the bactericidal action of the blood on the type-12 organism.

\section{Extracellular and acid-extractable $M$ protein in " throat" and "skin" serotypes}

The titres of $\mathrm{M}$ protein in the concentrated culture supernates ( $\mathrm{P} 66$ fractions) and corresponding acid extracts were determined by double diffusion in gel for 41 strains representing 25 different $M$ types. These strains were allotted to the "skin " or " throat" category according to their actual source, or by the classification of Wannamaker (1970) if the source was unknown. The strains were also divided into OF-positive and OF-negative categories, because previous work (Widdowson et al., 1971a) suggested that OF is closely associated with $M$ antigen and that there may be differences between the $M$ proteins of OF-positive and OF-negative serotypes.

The M-protein titres in acid extracts and culture supernates varied widely for different strains (table III). This might have been due to intrinsic differences in the ability of the strains to produce $M$ antigen, but unavoidable differences in the potency of antisera for the various types might also have been responsible. The OF-positive serotypes are particularly poor promoters of $\mathbf{M}$ antibody in rabbits (see Maxted and Widdowson, 1972; Widdowson et al., 1974) and this may have contributed to the notably low titres of $M$ protein observed for both acid extracts and P66 fractions of the OF-positive throat strains. In spite of this uncertainty, some general conclusions can be drawn about the relative amount of $\mathbf{M}$ protein in the supernate and acid extract of the same culture, if allowance is made for the fact that the volume of the P66 fraction of the supernate was five times that of the acid extract. The ratios of titre of P66 fraction $(\times 5)$ to the titre of acid extract for individual streptococcal strains are shown in table III, and the mean titres and ratios for the OF-positive and OF-negative strains in the "skin" and "throat" categories in table IV.

The M-protein titres in the acid extracts of the OF-negative "throat" strains were in general strikingly high; the mean value (24.28) was significantly higher than the mean for the other three groups $[t=6.02$ with 39 degrees of freedom (d.f.)] at the $P=0.001$ level. The means of the other three categories did not differ significantly from each other at the $P=0.05$ level.

There was more within-category variation in the M-protein content of the supernate fractions of all classes of strains; although the mean value for all the "throat" strains $(1 \cdot 7)$ was only about half the corresponding value for all 
TABLE III

Precipitation titres of extracellular (P66 fraction) and acid-extractable $M$ antigen in different serotypes

\begin{tabular}{|c|c|c|c|c|c|c|}
\hline \multirow{2}{*}{ Strain no. } & \multirow{2}{*}{ M type } & \multirow{2}{*}{$\begin{array}{l}\text { Opacity } \\
\text { factor }\end{array}$} & \multirow{2}{*}{$\begin{array}{l}\text { Serotype commonly } \\
\text { associated with } \\
\text { infection of }\end{array}$} & \multicolumn{2}{|c|}{ Precipitation titre* of } & \multirow{2}{*}{$\begin{array}{c}\text { Ratio of } \\
\text { titres of } \\
\text { supernate } \\
(\times 5) \dagger \text { and } \\
\text { extract }\end{array}$} \\
\hline & & & & $\begin{array}{c}\text { supernate } \\
\text { (P66 fraction) }\end{array}$ & $\begin{array}{l}\text { acid } \\
\text { extract }\end{array}$ & \\
\hline $\begin{array}{l}\text { SF130/13 } \\
\text { B920/24 } \\
\text { T5B/PS } \\
\text { R70/1648 } \\
\text { S43/78 } \\
\text { R67/3630 } \\
\text { R71/3015 } \\
\text { R55/1130 } \\
\text { R53/1077 } \\
\text { R71/2983 } \\
\text { R71/2992 } \\
\text { J17C } \\
\text { C98/97 } \\
\text { Quinn }\end{array}$ & $\begin{array}{r}1 \\
3 \\
5 \\
5 \\
6 \\
12 \\
12 \\
12 \\
12 \\
12 \\
12 \\
18 \\
24 \\
30\end{array}$ & Negative & Throat & $\begin{array}{r}<1 \\
<1 \\
4 \\
4 \\
<1 \\
<1 \\
<1 \\
<1 \\
4 \\
4 \\
4 \\
4 \\
<1 \\
4 \\
4\end{array}$ & $\begin{array}{l}16 \\
16 \\
32 \\
16 \\
16 \\
32 \\
16 \\
32 \\
16 \\
32 \\
32 \\
4 \\
64 \\
16\end{array}$ & $\begin{array}{r}<0.31 \\
<0.31 \\
0.63 \\
1.25 \\
1.25 \\
<0.15 \\
<0.31 \\
0.63 \\
1.25 \\
0.63 \\
0.63 \\
<1.25 \\
0.31 \\
1.25\end{array}$ \\
\hline $\begin{array}{l}\text { 2/44/R64 } \\
\text { SF59 } \\
4990 \\
\text { R71/3009 } \\
\text { R71/2998 } \\
\text { T11/54/4 }\end{array}$ & $\begin{array}{r}2 \\
2 \\
4 \\
4 \\
4 \\
11\end{array}$ & Positive & & $\begin{array}{l}<1 \\
1 \\
<1 \\
<1 \\
1 \\
<1\end{array}$ & $\begin{array}{l}2 \\
4 \\
8 \\
4 \\
4 \\
4\end{array}$ & $\begin{array}{r}<2.50 \\
1.25 \\
<0.63 \\
<1.25 \\
1.25 \\
<1.25\end{array}$ \\
\hline $\begin{array}{l}\text { R55/138 } \\
\text { Stock } \\
\text { R66/1094 } \\
\text { Hanson } \\
\text { Kingbird } \\
\text { NCTC10873 } \\
\text { R67/3281 } \\
\text { NCTC10875 }\end{array}$ & $\begin{array}{l}41 \\
41 \\
52 \\
53 \\
54 \\
55 \\
56 \\
57\end{array}$ & Negative & & $\begin{array}{r}<1 \\
1 \\
1 \\
4 \\
8 \\
4 \\
1 \\
16\end{array}$ & $\begin{array}{r}2 \\
8 \\
8 \\
8 \\
8 \\
16 \\
16 \\
4 \\
8\end{array}$ & $\begin{array}{r}<1.25 \\
0.63 \\
0.63 \\
2.50 \\
5.00 \\
1.25 \\
2.50 \\
10.00\end{array}$ \\
\hline $\begin{array}{l}1006 \mathrm{~S} \\
\text { R67/390 } \\
20 / 60 \\
13921 \\
\text { R69/3655 } \\
69886 \\
\text { B766 } \\
\text { C37411 } \\
\text { R71/2606 } \\
3884 \\
\text { R2709 } \\
\text { SF2 } \\
\text { PS346 }\end{array}$ & $\begin{array}{c}\text { Ala } 2 \ddagger \\
\text { Ala } 2 \\
25 \\
49 \\
49 \\
49 \\
49 \\
49 \\
58 \\
58 \\
60 \\
63 \\
\text { PS346 }\end{array}$ & Positive & Skin & $\begin{array}{r}<1 \\
<1 \\
1 \\
1 \\
2 \\
2 \\
4 \\
4 \\
4 \\
1 \\
2 \\
16 \\
8\end{array}$ & $\begin{array}{r}4 \\
2 \\
4 \\
4 \\
4 \\
4 \\
4 \\
4 \\
4 \\
8 \\
8 \\
16 \\
16\end{array}$ & $\begin{array}{r}<1.25 \\
<1.25 \\
1.25 \\
1.25 \\
2.50 \\
2.50 \\
5.00 \\
5.00 \\
5.00 \\
0.63 \\
1.25 \\
5.00 \\
2.50\end{array}$ \\
\hline
\end{tabular}

* Highest dilution giving a line of precipitation against the homologous M-antiserum.

$\uparrow$ The volume of the P66 fraction was five times greater than that of the corresponding acid extract.

$\ddagger$ T25/Imp19, M2 [see Dillon, Reeves and Maxted (1968)].

the "skin" strains (3.81) this difference was not significant at the $P=0.05$ level and was largely attributable to the very low values for the OF-positive "throat" strains. It is difficult to decide what conclusions should be drawn from this, because the antisera for some of the OF-positive serotypes were known to be very weak. 
TABLE IV

Comparison of $M$-antigen titres* (mean values) in concentrated culture supernates (P66 fractions) and acid extracts of OF-positive and OF-negative strains of "skin" and "throat" serotypes

\begin{tabular}{|c|c|c|c|c|}
\hline \multirow{2}{*}{ Category of strain } & \multirow{2}{*}{ Number of strains tested } & \multicolumn{2}{|c|}{ Mean value of $M$ titre in } & \multirow{2}{*}{$\begin{array}{l}\text { Ratio of mean } \\
\text { titres of } \\
\text { supernate }(\times 5) \dagger \\
\text { and extract }\end{array}$} \\
\hline & & supernate & acid extract & \\
\hline $\begin{array}{l}\text { OF-negative " skin " } \\
\text { OF-positive " skin" } \\
\text { OF-negative " throat", } \\
\text { OF-positive " throat" }\end{array}$ & $\begin{array}{r}8 \\
13 \\
14 \\
6\end{array}$ & $\begin{array}{l}4 \cdot 38 \\
3 \cdot 46 \\
2 \cdot 28 \\
0 \cdot 33\end{array}$ & $\begin{array}{c}7 \cdot 75 \\
6 \cdot 3 \\
24 \cdot 28 \\
4 \cdot 33\end{array}$ & $\begin{array}{l}2 \cdot 81 \\
2 \cdot 45 \\
0 \cdot 56 \\
0 \cdot 42\end{array}$ \\
\hline
\end{tabular}

* In precipitation tests against $\mathbf{M}$ antisera of homologous type.

$\dagger$ Volume of P66 fraction was five times greater than that of the corresponding acid extract. The mean ratios were calculated from the figures in column 7 of table III, and not from the mean values in columns 3 and 4 of this table. In the calculation of mean values, titres $<1$ and ratios derived from these were taken as zero.

The ratio of extracellular to extractable $M$ antigen (tables III and IV) was calculated to eliminate differences in potency of individual $\mathbf{M}$ antisera, so that more valid comparisons between the categories could be made. The mean ratios for both OF-positive and OF-negative " throat" strains were both low and not significantly different from each other at the $P=0.05$ level. The mean ratios for OF-positive and OF-negative "skin" strains were not significantly different from each other, but the mean ratio for all the "skin" strains was significantly higher at the $\mathbf{P}=0.001$ level than the corresponding value for all the " throat" strains $(t=3.65$ with 39 d.f.). Thus, it appears that " throat" strains have 2-3 times more of the extractable than of the extra-cellular M protein, but that "skin" strains have between 2.5-3.0 times more of the extracellular than of the extractable $M$ protein.

Most of the "skin" strains (15 of 21) had ratios of extracellular to extractable $\mathrm{M}$ protein $>1.25$; of the six strains that had lower ratios all produced extracellular proteinase, although the medium used for growth was designed to depress proteinase formation (Ball, 1972). Nevertheless destruction of extracellular $M$ antigen may have been responsible for the low ratios from these strains. However, the 14 of 20 " throat" strains that gave low ratios produced no proteinase under these conditions.

It seemed possible that hyaluronic acid capsules, which are formed more often by "throat" strains than by "skin" strains, might cause retention of $\mathrm{M}$ antigen on the cells. Mucoid strains of M-types 5, 12, 30 and a non-mucoid strain of M-type 49 were grown in the presence of hyaluronidase (from bovine testes, BDH) $0.004 \%(w / v)$, an amount of enzyme that was sufficient to destroy the hyaluronic acid capsule of the mucoid strains. However, no increase in the ratio of extracellular to extractable $M$ antigen resulted from growth in hyaluronidase.

Molecular-weight distribution. Our earlier studies on crude $0.2 \mathrm{M}$-acid extracts (Widdowson et al., 1971a; Maxted and Widdowson, 1972) had shown that OF, when formed, was detectable only in the larger-molecular-weight 
fractions eluted at or just behind the void volume of a G100 Sephadex column; this indicated a molecular weight of $c .80000$ to 100000 . Most of the acidextracted $\mathrm{M}$ protein of OF-positive strains was also eluted in this range, but some $\mathrm{M}$ protein, unaccompanied by $\mathrm{OF}$, was detected by precipitation tests in fractions corresponding to molecular weights in the 5000-80 000 range. The acid extracts of OF-negative strains had no protein peak at the void volume, and a large number of fractions contained $M$ protein, but the strongest reactions were obtained in the middle of the molecular-weight range.

It has never been established whether the wide molecular-weight distribution of acid-extracted $\mathbf{M}$ proteins is due to fragmentation by acid, or whether $\mathbf{M}$ proteins exist naturally in multiple molecular forms. We therefore compared the molecular-weight distribution on Sephadex G100 of acid extracts of strains of "skin" and "throat" serotypes belonging to both the OF-positive and OF-negative categories with the molecular-weight distributions of the M-protein fractions from the " matching" culture supernates.

Table $\mathrm{V}$ shows that both the extracellular and acid-extracted $\mathrm{M}$ protein of OF-negative "throat" strains of serotypes 5,12 and 30 had a very wide molecular weight distribution, as observed previously for the acid extracts of OF-negative strains. The M protein of the OF-positive " throat" strain (type 4) had a more restricted distribution, but again there was little difference between the extracellular and acid-extracted antigen. On the other hand, all of the skin strains, whether OF-positive or -negative, gave strikingly different molecular-weight distributions of serologically-active $\mathbf{M}$ protein in their culture supernates and acid extracts. The molecular weight distribution in the acid extracts was very wide (c. 5000 to $\geqq 150000$ ) but the active material of the culture supernates was all of large molecular weight (c. 55000 to $\geqq 150000$ ).

Acid extracts and concentrated culture supernates of the strains of the OF-positive serotypes tested (types 4, 49 and 60) all contained OF and this was associated only with the higher molecular-weight fractions (see table V).

\section{Discussion}

Extracellular $\mathbf{M}$ protein in cultures of group A streptococci was demonstrated by Olarte (1948), but until recently the character and distribution of the antigen has received little attention. Our results show that streptococci of a wide variety of serotypes form extracellular $\mathbf{M}$ protein which may be released from the cell early in the growth cycle. Extracellular M protein is serologically indentical with acid-extracted $M$ protein of the same serotype in double-diffusion tests in gel, and its presence was confirmed by complementfixation tests with homologous anti-M sera and by the neutralisation of homologous protective antibody in human serum. The serological reactivity of extracellular $\mathbf{M}$ protein survives heat and acid treatment, but like acid-extracted antigen is destroyed by proteolytic enzymes. The isoelectric point of type-12 extracellular $M$ protein is the same as that of the acid-extracted antigen, and both proteins are focused in the $p \mathrm{H}$ range 4.5 to 5.8 with a peak at $p \mathrm{H} 5.0$ to $5 \cdot 1$. 
STREPTOCOCCAL M PROTEINS

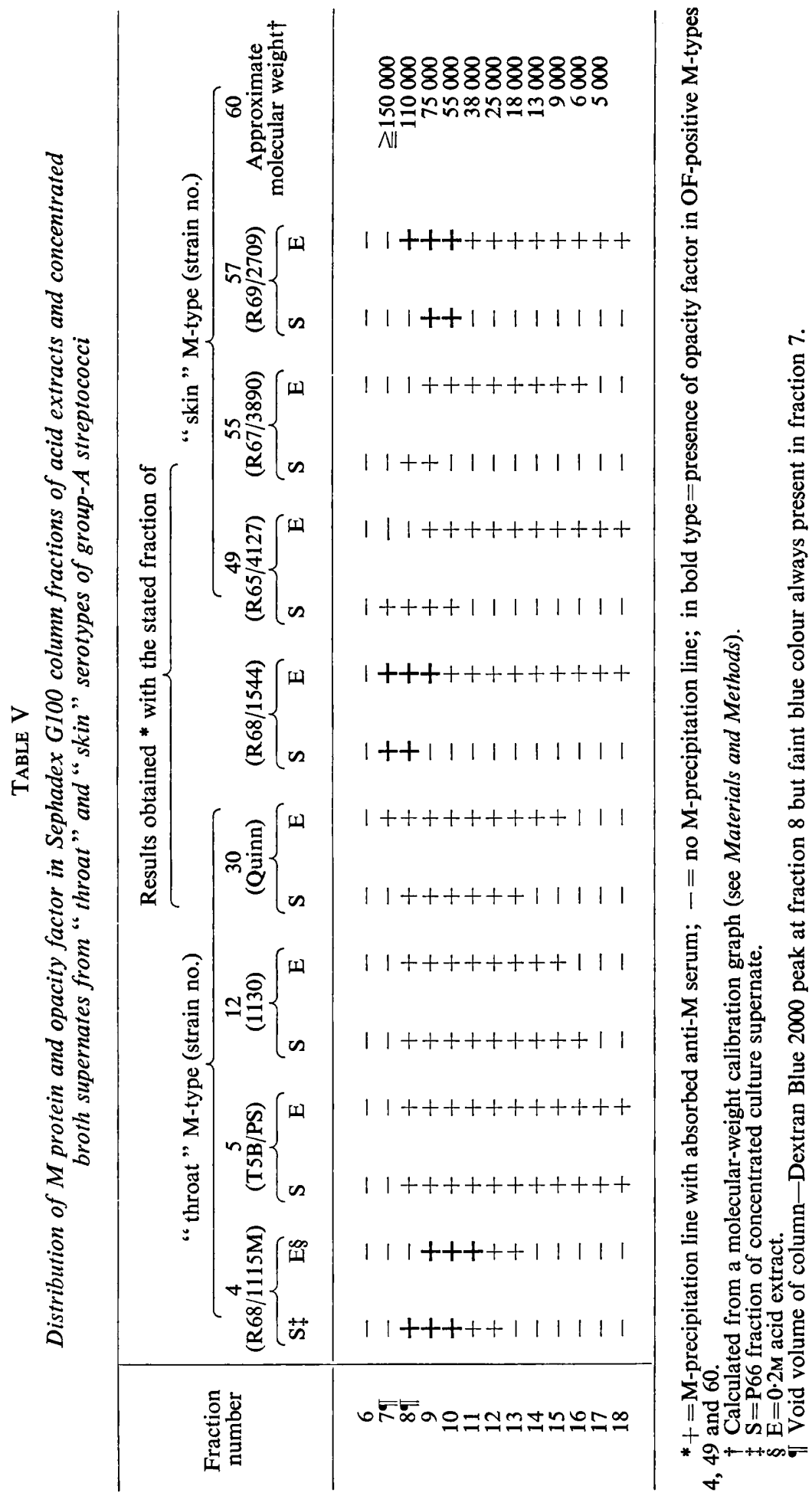


It is difficult to compare absolute amounts of $\mathrm{M}$ protein formed or extracted from members of different serotypes because of variation in the quality of the corresponding $\mathrm{M}$ antisera. We therefore compared, under standard conditions, the amount of $M$ antigen in the supernate with that extractable from the cells by acid, and found that in general the ratios of extracellular to acid-extractable $M$ protein were greatest in strains commonly associated with pyoderma. This suggests that the $M$ protein of these strains may be less firmly bound to the cell or that the cell-bound antigen is more sensitive to heat and acid than the cell-bound $M$ proteins of respiratory serotypes, or both. It is not possible to distinguish between these alternatives without further work, but the results (tables III and IV) suggest strongly that the OF-negative " throat" strains in particular have about four times more extractable $\mathbf{M}$ antigen than either the OF-positive or OF-negative " skin" strains.

It is difficult to be sure whether this finding has any bearing on the practical difficulties of M-typing pyoderma strains. Some workers have suggested that members of "skin" serotypes may be " deficient" in M antigen (Markowitz et al., 1965; Wannamaker, 1967), but a more likely explanation of the low rate of typability of streptococci from skin lesions is the unavailability of the necessary M-typing antisera (see Wannamaker, 1970). This, in its turn, is partly attributable to the poor M-antibody response of rabbits to most " skin " streptococci, particularly those belonging to OF-positive serotypes (see Maxted and Widdowson, 1972). Among "throat" serotypes, surface M protein appears to be essential for the establishment of clinical disease in the upper respiratory tract; and it may play an important role in attachment of the streptococcus to epithelial cells (Ellen and Gibbons, 1972) as well as protection of the organism from phagocytosis (Wiley and Wilson, 1956). M-positive "skin" strains also resist phagocytosis (Top et al., 1967), but the role of $\mathrm{M}$ antigen in the pathogenesis of impetigo is uncertain.

Information about the type-specific antibody response after skin infection is incomplete. In pyoderma in man, a generally low frequency and magnitude of response has been reported (Potter et al., 1968; Dillon and Derrick, 1974; Widdowson et al., 1974), in comparison with the response in patients recovering from throat infections. Repeated experimental skin infection of the hamster with M-type 57-an OF-negative serotype-induced no type-specific protection (Dajani and Wannamaker, 1970). Whether this poor antibody response is due to the site of infection or to qualitative or quantitative differences in the $\mathbf{M}$ proteins is unknown. The immunogenicity of extracellular $\mathbf{M}$ antigen has not been investigated, but it is possible that this soluble $\mathbf{M}$ protein may be less immunogenic than the cell-bound form.

The axial ratios of the $M$ proteins of OF-positive or "skin" serotypes, have not been determined, but both the high- and low-molecular-weight components of type-12 $\mathrm{M}$ protein have been shown to be rod-shaped rather than globular (Pappenheimer, Williams and Zittle, 1942; Fox and Wittner, 1969). The molecular-weight values obtained by Sephadex G100 chromatography must therefore be accepted only for comparative studies of molecular weights because this method gives accurate estimates for globular proteins only 
(Andrews, 1964). The narrow range of molecular weights of the extracellular form of the $M$ proteins of members of the "skin" serotypes $49,55,57$ and 60 (corresponding to a molecular weight of $55000-\geqq 150000$ ) contrasted strongly with the extremely wide range of the corresponding acid-extracted $\mathbf{M}$ proteins (molecular weight $=5000-\geqq 150000$ ). This is consistent with the view that acid extraction may cause extensive fragmentation of the native M-protein molecule in these serotypes. On the other hand, almost identical elution profiles were obtained for both the acid-extracted and extracellular form of M protein from strains of throat serotypes 5, 12 and 30, suggesting that the smaller pieces of $M$ protein in acid extracts of these types may not be the result of breakdown of a larger molecule by acid. Whether these small fragments in the supernate represent proteins at an incomplete stage of synthesis or are the result of enzymatic breakdown of a larger molecule is not known.

We have not investigated the role of aggregation on the apparent molecularsize distribution of acid-extracted or extracellular M proteins. Fischetti et al., (1973) have shown that this may be important, and have suggested that the large M-protein molecules yielded by some methods of extraction may be due to extensive aggregation that is difficult to reverse. The occurrence of highmolecular-weight fractions of $\mathbf{M}$ protein in culture supernates was much more striking with "skin" strains than with "throat" strains, suggesting that the $M$ proteins of the former may have a greater tendency to aggregate than those of the latter.

\section{SUMMARY}

$M$ protein was detected in the concentrated broth-culture supernates of strains of group-A streptococci, belonging to a wide variety of $M$ types, by double-diffusion in gel, and its presence was confirmed in several strains of M-type 12 by complement fixation with absorbed anti-M serum and by the neutralisation of human " bactericidal " antibody. Extracellular M proteins retained their serological activity after heating at $95^{\circ} \mathrm{C}$ for $10 \mathrm{~min}$. at neutral or acid $p \mathrm{H}$, but were destroyed by proteolytic enzymes. Both the acid-extracted and extracellular M proteins of a type-12 strain had isoelectric points between $p \mathrm{H} 5 \cdot 0$ and $5 \cdot 1$.

The ratios of extracellular to acid-extractable $\mathbf{M}$ protein were significantly higher in $\mathbf{M}$ types associated with pyoderma than in those associated with infection of the upper respiratory tract. This was related to a striking tendency for "skin" strains to have less extractable $M$ protein than many of the " throat" strains, and to the fact that only $50 \%$ of the "throat" strains had detectable extracellular M protein. On the other hand the majority of " skin" strains (18 of 21) produced extracellular $M$ antigen. The molecular-weight distribution in extracellular and acid-extracted $\mathbf{M}$ proteins was inferred from chromatography on Sephadex G100 of culture supernates and corresponding acid extracts. In the " respiratory" $M$-types 5, 12 and 30 the range of molecular weights was wide ( 5000 to $\geqq 150000$ ) and very similar in the two preparations. In the "skin" serotypes $49,55,57$ and 60 , however, extracellular M protein fell into the range 55000 to $\geqq 150000$, a distribution strikingly different from 
that in the acid extracts of the corresponding strains (5000 to $\geqq 150000$ ). This suggests that acid extraction may modify the $M$ proteins of pyoderma serotypes more than those of respiratory serotypes.

\section{REFERENCES}

ANDREws, P. 1964. Estimation of the molecular weights of proteins by Sephadex Gelfiltration. Biochem. J., 91, 222.

BALL, L. C. 1972. The influence of Neopeptone on the formation of M-antigen by group A streptococci in culture. Med. Lab. Technol., 29, 18

Beachey, E. H., Alberti, H. ANd Stollerman, G. H. 1969. Delayed hypersensitivity to purified streptococcal $M$ protein in guinea pigs and in man. J. Immun., 102, 42.

Bradstreet, C. M. P. AND TAYloR, C. E. D. 1962. Technique of complement fixation test applicable to the diagnosis of virus diseases. Mon. Bull. Minist. Hlth, 21, 96.

CruickshaNK, R.1965. Medical microbiology, 11th ed., Edinburgh and London, p. 742.

Dajani, A. S. AND Wannamaker, L. W. 1970. Experimental infection of the skin in the hamster simulating human impetigo. I. Natural history of the infection. J. infect. Dis., 122, 196.

Dillon, H. C. AND Derrick, C. W. 1974. Recent studies of streptococcal skin and throat infections in Alabama. In Streptococcal Disease and the Community, Proceedings of 5th International Symposium on Streptococcus pyogenes, edited by M. J. Haverkorn, Amsterdam, p. 266.

Dillon, H. C., Reeves, M. S. AND MaXTed, W. R. 1968. Acute glomerulonephritis following skin infection due to streptococci of M-type 2. Lancet, 1, 543.

Ellen, R. P. AND Gibbons, R. J. 1972. M protein-associated adherence of Streptococcus pyogenes to epithelial surfaces: prerequisite for virulence. Infect. Immun., 5, 826.

Fischetti, V. A., Gotschlich, E. C., Siviglia, G. And Zabriskie, J. B. 1973. The sub-unit structure of streptococcal M protein. Abstr. A. Meeting Am. Soc. Microbiol., 242, p. 181.

Fox, E. N. AND Wittner, M. K. 1965. The multiple molecular structure of the M proteins of group A streptococci. Proc. natn. Acad. Sci. U.S.A., 54, 1118.

Fox, E. N. AND WitTNer, M. K. 1969. New observations on the structure and antigenicity of the $\mathrm{M}$ proteins of the group A streptococcus. Immunochemistry, 6,11 .

GrIfFITH, F. 1934. The serological classification of Streptococcus pyogenes. J. Hyg., Camb., $34,542$.

LANCEFIELD, R. C. 1928. The antigenic complex of Streptococcus haemolyticus. 1. Demonstration of a type-specific substance in extracts of Streptococcus haemolyticus. J. exp. Med., 47, 91.

Lancefield, R. C. and Perlmann, G. E. 1952. Preparation and properties of type-specific $\mathrm{M}$ antigen isolated from a group $\mathrm{A}$, type 1 , hemolytic streptococcus. J. exp., Med., 96, 71.

Lowry, O. H., Rosebrough, N. J., FARR, A. L. AND Randall, R. J. 1951. Protein measurement with the Folin phenol reagent. J. biol. Chem., 193, 265

Markowitz, M., Bruton, H. D., Kuttner, A. G. And Cluff, L. E. 1965. The bacteriologic findings, streptococcal immune response and renal complications in children with impetigo. Pediatrics, Springfield, 35, 393.

MaXted, W. R. ANd Valkenburg, H. A. 1969. Variation in the M-antigen of group A streptococci. J. med. Microbiol., 2, 199.

Maxted, W. R. AND Widdowson, J. P. 1972. The protein antigens of group A streptococci. The $\mathrm{M}$ and $\mathrm{T}$ proteins. In Streptococci and streptococcal diseases: recognition, understanding and management, edited by L. W. Wannamaker and J. M. Matsen, London and New York, p. 251.

Olarte, J. 1948. Demonstration of the " $M$ " protein in culture filtrates of hemolytic streptococci of group A. J. Immun., 58, 15. 
Pappenheimer, A. M., Williams, J. W. And Zittle, C. A. 1942. The antigen structure of hemolytic streptococci of Lancefield group A. IX. Some physical properties of the M-protein. J. Immun., 43, 61.

Potter, E. V., Moran, A. F., Poon-King, T. and Earle, D. 1968. Characteristics of beta hemolytic streptococci associated with acute glomerulonephritis in Trinidad, West Indies. J. Lab. clin. Med., 71, 126.

Strauss, D. C. AND LANGE, C. F. 1972. Immunochemistry and end-group analysis of group A streptococcal $\mathrm{M}$ proteins. Infect. Immun., 5, 927.

Swift, H. F., Wilson, A. T. and Lancefield, R. C. 1943. Typing group A hemolytic streptococci by $\mathrm{M}$ precipitin reactions in capillary pipettes. J. exp. Med., 78, 127.

Top, F. H., Wannamaker, L. W., Maxted, W. R. and Anthony, B. F. 1967. M antigens among group A streptococci isolated from skin lesions. J. exp. Med., 126, 667.

Vosti, K. L., JoHNSON, R. H. AND Dillon, M. F. 1971. Further characterization of purified fractions of $\mathrm{M}$ protein from a strain of group A type 12 streptococcus. J. Immun., 107, 104.

WANNAMAKER, L. W. 1967. Epidemiology of acute glomerulonephritis. In Acute Glomerulonephritis: proceedings of the 17th annual conference of the kidney, edited by J. Metcoff, Boston, p. 39.

Wannamaker, L. W. 1970. Differences between streptococcal infections of the throat and of the skin. New Eng. J. Med., 282, 23 and 78.

Widdowson, J. P., MaXted, W. R. AND GRANT, D. L. 1970. The production of opacity in serum by group A streptococci and its relationship with the presence of $M$ antigen. J. gen. Microbiol., 61, 343.

Widdowson, J. P., Maxted, W. R., Grant, D. L. And Pinney, A. M. 1971a. The relationship between M-antigen and opacity factor in group A streptococci. J. gen. Microbiol., $65,69$.

Widdowson, J. P., Maxted, W. R., Notley, C. M. And Pinney, A. M. 1974. Type-specific and $\mathrm{M}$-associated antibody response to different serotypes of group A streptococci. In Streptococcal disease and the community, Proceedings of the 5th international symposium on Streptococcus pyogenes, edited by M. J. Haverkorn, Amsterdam, p. 116.

Widdowson, J. P., MaXted, W. R. ANd Pinney, A. M. 1971b. An M-associated protein antigen of group A streptococci. Journal of Hygiene, Cambridge, 69, 553.

Wiley, G. G. AND WiLson, A. T. 1956. The ability of group A streptococci killed by heat or mercury arc irradiation to resist ingestion by phagocytes. J. exp. Med., 103, 15 . 